\title{
THE EFFECT OF CHANGES IN POSTURE AND OF GRADED EXERCISE ON STROKE VOLUME IN MAN*
}

\author{
By YANG WANG, $\dagger$ ROBERT J. MARSHALL AND JOHN T. SHEPHERD \\ (From the Mayo Clinic and Mayo Foundation, $\ddagger$ Rochester, Minn.)
}

(Submitted for publication December 31, 1959; accepted March 17, 1960)

Interest has been revived recently in the relative importance of changes in heart rate and stroke volume during exercise in man. Rushmer and Smith have examined the literature and concluded that an increase in stroke volume is not an essential feature of the ventricular response in normal human subjects $(1,2)$. Contrary views, particularly in the older literature, were attributed to differences in the technics used to measure cardiac output and in the degree of training of the subjects (1). However, in the studies reviewed by Rushmer, the subjects had exercised in various postures. This could have accounted for much of the apparent discrepancy (3), a point which Rushmer has now emphasized (4).

The present investigation demonstrates the importance of the posture of the subject in the interpretation of changes in stroke volume from rest to exercise. The stroke volume increases only slightly once exercise has begun, regardless of the severity of the exercise or the position assumed by the subject.

\section{METHODS}

Seven healthy "untrained" men, aged 25 to 35 years, were studied. Cardiac output was measured by the indicator-dilution method. A cardiac catheter was placed with its tip in the superior vena cava. The indicator, cardio-green dye, ${ }^{1}$ was given in a dose of $7.5 \mathrm{mg}$ by sudden injection from a specially calibrated syringe. The syringe was attached to the catheter throughout the experiment and was filled before each injection from a supply syringe connected to it by a three-way tap. Blood was sampled continuously for each dilution curve from the radial artery through a Wood oximeter at

* This investigation was supported in part by a grant from the Minnesota Heart Association.

$\dagger$ Minnesota Heart Association, Fellow in Physiology, Mayo Foundation.

$¥$ The Mayo Foundation, Rochester, Minnesota, is a part of the Graduate School of the University of Minnesota.

${ }^{1}$ Kindly supplied by Hynson, Westcott and Dunning, Baltimore, Md. rates of 28 to $50 \mathrm{ml}$ per minute. The dilution curve was recorded on a photokymograph. Not more than $40 \mathrm{ml}$ was withdrawn for any curve. On completion of each curve the blood was reinfused.

Samples of blood were withdrawn from the radial artery before and after each experiment. Known amounts of dye were added to $10 \mathrm{ml}$ aliquots of blood and the resulting mixtures were drawn through the cuvet oximeter to permit calibration of the dilution curves. The calibrations for the two samples invariably were close (Figure 1, upper panel) and were reproducible from day to day. Calibrations for blood from different subjects were similar. Figure 1 (lower panel) also shows the mean values and 95 per cent confidence limits for 14 sets of observations from the 4 subjects who performed exercise
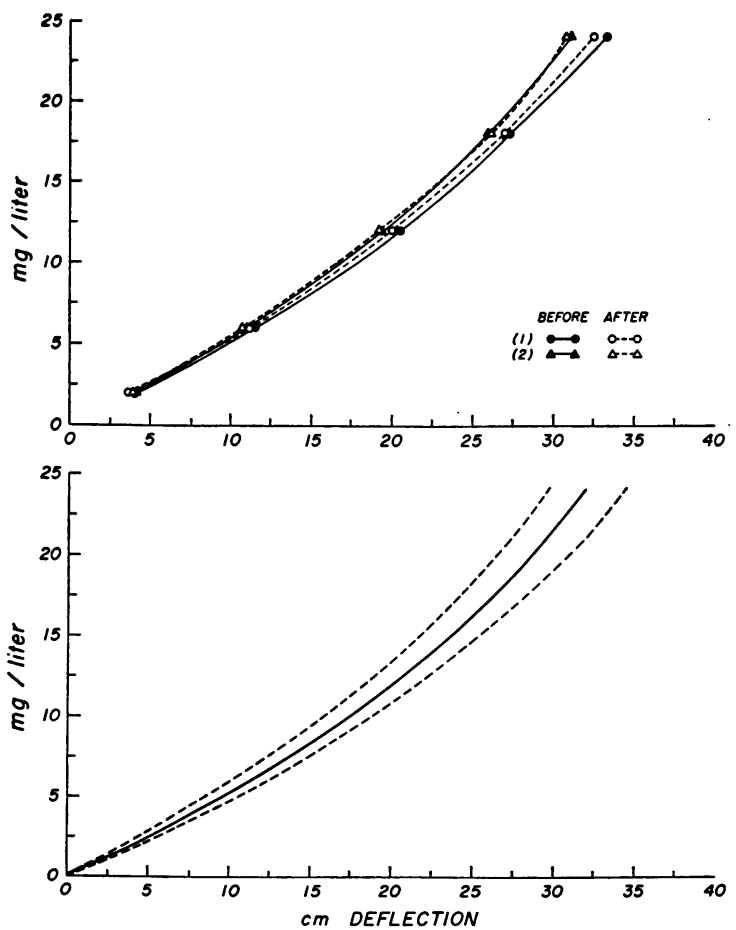

Fig. 1. Calibrations of Dye-blood mixtures for SAMPLES TAKEN BEFORE AND AFTER A COMPLETE EXPERIMENT ON EACH OF TWO OCCASIONS IN R.M. (UPPER PANEL); MEAN VALUES AND 95 PER CENT CONFIDENCE LIMITS OF CALIBRATIONS FOR 14 BLOOD SAMPLES IN SIX SUBJECTS (LOWER PANEL). The same cuvet oximeter was used on every occasion. 
in the upright position and from 2 additional subjects, the same cuvet oximeter being used on each occasion.

The heart rate was recorded by an electrocardiograph and a cardiotachometer. Radial artery pressure was recorded continuously except during inscription of the indicator-dilution curves.

In some experiments expired air was collected in a neoprene bag for 5 minutes with the subject at rest and for periods of 1 or 2 minutes during each period of exercise. Low resistance valves and tubing were used. The oxygen consumption so measured was used only to provide an index of energy expenditure. Surface area was determined from each subject's height and weight by the nomogram of Dubois and Dubois (5).

In 9 experiments observations were made first on 4 subjects at rest in the supine position. The observations were then repeated after the subject stood for 15 to 20 minutes in a relaxed manner. This was followed by mild leg exercise, consisting of alternate contraction and relaxation of the calf muscle or marking time. Subsequent measurements were made with the subject walking up a treadmill, tilted at 12 degrees from the horizontal, at 1.7, $2.5,3.5$, and 4.5 miles per hour ( $\mathrm{mph}$ ). Successive series of exercises were separated by periods of 10 to $15 \mathrm{~min}$ utes during which the subject stood at ease or gently contracted his calf muscles. The right forearm and hand were fastened to a horizontal board at, or slightly below, heart level and the left hand gripped the board. The zero reference point for arterial pressure measurements was taken as halfway between the front and back of the thorax while the subject was in the supine position and at the level of the third costal cartilage while he was standing or walking. At each exercise the indicator-dilution curve was recorded during the third minute.

Cardiac output and heart rate were measured during the performance of leg exercise in 4 supine subjects. Two of the subjects in further experiments walked on the treadmill at $3.5 \mathrm{mph}$ for 10 to 11 minutes. During this period the heart rate was monitored continuously and indicator-dilution curves were obtained at intervals.

\section{RESULTS}

Indicator-dilution curves obtained in the first experiment on Subject Y.W. are shown in Figure 2. With the subject standing at rest the cardiac output was $5.7 \mathrm{~L}$ per minute, the heart rate 98 beats per minute, and the stroke volume $58 \mathrm{ml}$. When the subject walked at $3.5 \mathrm{mph}$ up the inclined treadmill the cardiac output increased to $18.8 \mathrm{~L}$ per minute and the heart rate to 164 beats per minute; the stroke volume $(115 \mathrm{ml})$ was doubled.

Data from the nine experiments on the four subjects who performed exercise in the upright position are shown in Figure 3 and summarized in Table I. During rest in the supine position the cardiac output was between 6.1 and $7.5 \mathrm{~L}$ per min-
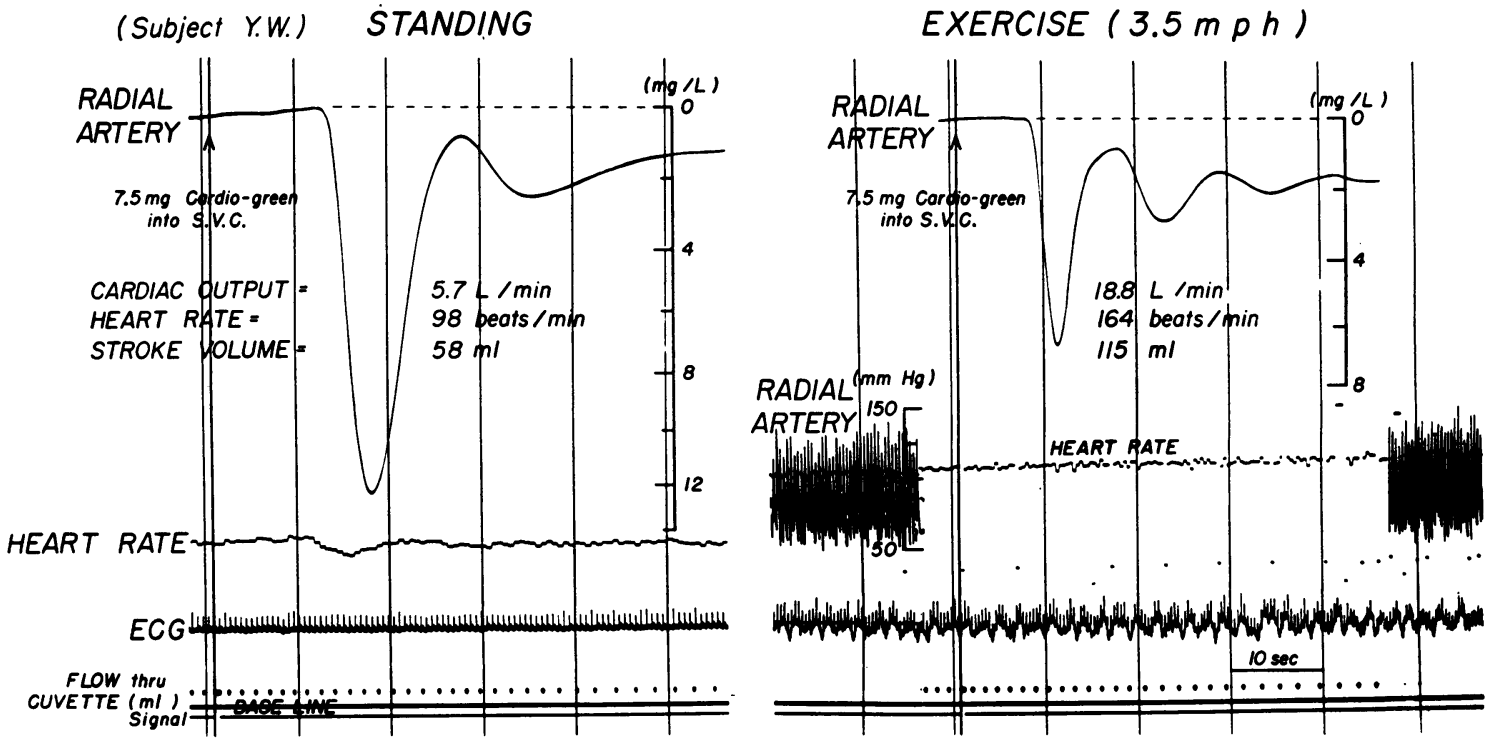

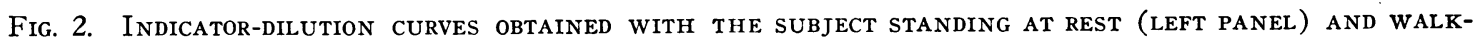
ING AT 3.5 MPH ON THE INCLINED TREADMILl (RIGHT PANEL). The calibrations are shown on the right. The vertical lines with arrow heads indicate the time of injection. Beneath are shown the cardiotachometer record of heart rate, the electrocardiogram, and the interrupted line signaling the passage of each milliliter of blood through the cuvet. In the right panel the radial artery pressure also is shown; the instability of the baseline in the electrocardiogram is due to the rapid deep respirations. 
TABLE I

Changes in cardiac output, pulse rate, stroke volume, oxygen consumption and blood pressure during upright exercise

\begin{tabular}{|c|c|c|c|c|c|c|c|c|c|}
\hline \multirow{2}{*}{$\begin{array}{l}\text { Subj. } \\
\text { BSA }\end{array}$} & & \multicolumn{2}{|c|}{ Position } & \multicolumn{2}{|c|}{ Light exercise* } & \multicolumn{4}{|c|}{ Walking speed (mph) } \\
\hline & & Supine & Standing & A & B & 1.7 & 2.5 & 3.5 & 4.5 \\
\hline $\begin{array}{l}\text { D.W. } \\
\left(1.91 \mathrm{~m}^{2}\right)\end{array}$ & $\begin{array}{l}\text { [1] C.O. } \\
\text { P.R. } \\
\text { S.V. } \\
\text { O. }_{2} \\
\text { B.P. }\end{array}$ & $\begin{array}{l}7.2 \\
63 \\
114 \\
280 \\
140 / 75\end{array}$ & $\begin{array}{c}6.8 \\
83 \\
82 \\
125 / 75\end{array}$ & & & $\begin{array}{l}14.7 \\
128 \\
115 \\
1,500 \\
135 / 75\end{array}$ & $\begin{array}{l}17.5 \\
150 \\
117 \\
1,970 \\
150 / 75\end{array}$ & $\begin{array}{l}20.3 \\
170 \\
119 \\
2,380 \\
165 / 80\end{array}$ & \\
\hline & $\begin{array}{l}\text { [2] C.O. } \\
\text { P.R. } \\
\text { S.V. } \\
\text { B.P. }\end{array}$ & $\begin{array}{c}6.7 \\
68 \\
98 \\
120 / 70\end{array}$ & $\begin{array}{c}4.1 \\
87 \\
47 \\
120 / 80\end{array}$ & & & $\begin{array}{c}11.3 \\
116 \\
97 \\
150 / 75\end{array}$ & $\begin{array}{l}16.7 \\
141 \\
118 \\
160 / 80\end{array}$ & $\begin{array}{l}16.6 \\
157 \\
106 \\
160 / 85\end{array}$ & \\
\hline & $\begin{array}{l}\text { [3] C.O. } \\
\text { P.R. } \\
\text { S.V. } \\
\mathrm{O}_{2} \\
\text { B.P. }\end{array}$ & $\begin{array}{l}7.5 \\
72 \\
104 \\
280 \\
135 / 75\end{array}$ & $\begin{array}{l}4.0 \\
90 \\
44 \\
305 \\
135 / 75\end{array}$ & $\begin{array}{l}8.1 \\
87^{7.1} \\
890 \\
135 / 70\end{array}$ & & $\begin{array}{l}16.1 \\
130 \\
124 \\
140 / 65\end{array}$ & $\begin{array}{l}17.2 \\
132 \\
130 \\
140 / 65\end{array}$ & $\begin{array}{l}21.6 \\
168 \\
129 \\
\\
155 / 75\end{array}$ & $\begin{array}{l}20.0 \\
174 \\
114 \\
160 / 75\end{array}$ \\
\hline $\begin{array}{l}\text { R.M. } \\
\left(2.10 \mathrm{~m}^{2}\right)\end{array}$ & $\begin{array}{l}\text { [1] C.O. } \\
\text { R.P. } \\
\text { S.V. } \\
\mathrm{O}_{2} \\
\text { B.P. }\end{array}$ & $\begin{array}{l}6.9 \\
66 \\
104 \\
300 \\
130 / 65\end{array}$ & $\begin{array}{c}6.2 \\
87 \\
71 \\
115 / 65\end{array}$ & & & $\begin{array}{l}14.3 \\
133 \\
108 \\
1,530 \\
175 / 65\end{array}$ & \begin{tabular}{l}
\multicolumn{1}{c}{20.7} \\
170 \\
122 \\
2,410 \\
$185 / 65$
\end{tabular} & & \begin{tabular}{l}
\multicolumn{1}{l}{25.6} \\
180 \\
143 \\
2,820 \\
$180 / 65$
\end{tabular} \\
\hline & $\begin{array}{l}\text { [2] C.O. } \\
\text { P.R. } \\
\text { S.V. } \\
\text { B.P. }\end{array}$ & $\begin{array}{c}\quad 6.5 \\
58 \\
111 \\
115 / 65\end{array}$ & $\begin{array}{c}7.1 \\
75 \\
94 \\
130 / 75\end{array}$ & & & & & $\begin{array}{l}20.0 \\
165 \\
121 \\
200 / 70\end{array}$ & $\begin{array}{l}20.9 \\
177 \\
118 \\
200 / 70\end{array}$ \\
\hline & $\begin{array}{l}\text { [3] C.O. } \\
\text { R.P. } \\
\text { S.V. } \\
\mathrm{O}_{2} \\
\text { B.P. }\end{array}$ & $\begin{array}{l}7.4 \\
63 \\
117 \\
320 \\
115 / 65\end{array}$ & $\begin{array}{l}5.8 \\
82 \\
71 \\
340 \\
120 / 70\end{array}$ & $\begin{array}{l}8.0 \\
80 \\
100 \\
490 \\
150 / 70\end{array}$ & $\begin{array}{l}12.2 \\
104 \\
117 \\
1,000 \\
145 / 65\end{array}$ & & $\begin{array}{c}15.5 \\
158 \\
98 \\
170 / 70\end{array}$ & $\begin{array}{l}20.0 \\
177 \\
113 \\
200 / 75\end{array}$ & $\begin{array}{l}22.3 \\
183 \\
122 \\
205 / 75\end{array}$ \\
\hline $\begin{array}{l}\text { Y.W. } \\
\left(1.85 \mathrm{~m}^{2}\right)\end{array}$ & $\begin{array}{l}\text { [1] C.O. } \\
\text { P.R. } \\
\text { S.V. } \\
\text { O. } \\
\text { B.P. }\end{array}$ & $\begin{array}{l}6.6 \\
68 \\
97 \\
280 \\
120 / 70\end{array}$ & $\begin{array}{l}5.7 \\
98 \\
58 \\
260 \\
105 / 70\end{array}$ & & & $\begin{array}{c}11.1 \\
120 \\
93 \\
1,240 \\
120 / 50\end{array}$ & $\begin{array}{l}12.7 \\
132 \\
96 \\
1,360 \\
115 / 55\end{array}$ & $\begin{array}{l}18.8 \\
164 \\
115 \\
1,840 \\
125 / 60\end{array}$ & $\begin{array}{l}20.2 \\
174 \\
116 \\
2,150 \\
140 / 70\end{array}$ \\
\hline & $\begin{array}{l}\text { [2] C.O. } \\
\text { P.R. } \\
\text { S.V. } \\
\text { O. } \\
\text { B.P. }\end{array}$ & $\begin{array}{c}6.1 \\
65 \\
93 \\
120 / 65\end{array}$ & $\begin{array}{l}\quad 4.6 \\
84 \\
55 \\
300 \\
110 / 65\end{array}$ & $\begin{array}{c}7.3 \\
80 \\
92 \\
360 \\
120 / 65\end{array}$ & & & & $\begin{array}{l}19.2 \\
165 \\
116 \\
130 / 60\end{array}$ & \\
\hline $\begin{array}{l}\text { D.H. } \\
\left(1.73 \mathrm{~m}^{2}\right)\end{array}$ & $\begin{array}{c}\text { [1] C.O. } \\
\text { P.R. } \\
\text { S.V. } \\
\text { O. } \\
\text { B.P. }\end{array}$ & $\begin{array}{l}6.2 \\
65 \\
96 \\
260 \\
130 / 60\end{array}$ & $\begin{array}{l}4.6 \\
89 \\
52 \\
270 \\
115 / 55\end{array}$ & & & $\begin{array}{c}8.8 \\
96 \\
92 \\
1,080 \\
140 / 55\end{array}$ & $\begin{array}{c}12.1 \\
126 \\
95 \\
1,640 \\
140 / 50\end{array}$ & $\begin{array}{c}15.3 \\
166 \\
92 \\
2,030 \\
155 / 55\end{array}$ & $\begin{array}{c}14.9 \\
168 \\
89 \\
1,840 \\
165 / 55\end{array}$ \\
\hline
\end{tabular}

${ }^{*} \mathrm{~A}=$ contraction and relaxation of calf muscles; $\mathrm{B}=$ marking time.

ute. The average cardiac index for all observations was $3.7 \mathrm{~L}$ in D.W., $3.3 \mathrm{~L}$ in R.M., and $3.4 \mathrm{~L}$ in Y.W.; the cardiac index was $3.6 \mathrm{~L}$ in D.H. for a single observation. The average cardiac index for all subjects was $3.5 \mathrm{~L}$. The pulse rates were from 58 to 72 beats per minute, the systemic blood pressure from $115 / 65$ to $140 / 75 \mathrm{~mm}$ of mercury, and the stroke volume from 93 to $117 \mathrm{ml}$. Table II shows the stroke index which ranged from 51 to $56 \mathrm{ml}$ (average, $54 \mathrm{ml}$ ) and was similar from 

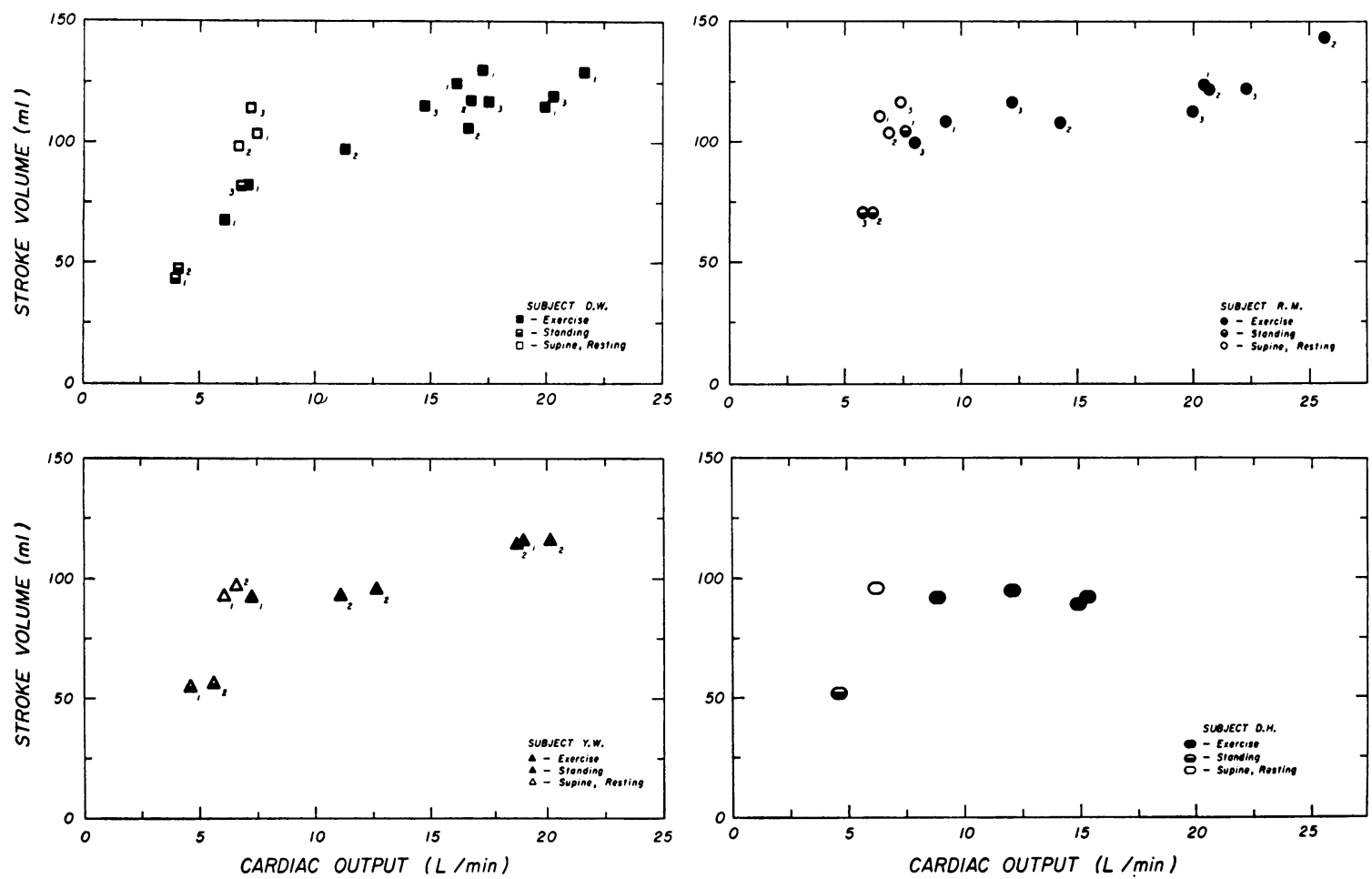

Fig. 3. Changes in stroke volume and CARdiac output in EACh of the four subjects. White symbols, data for subjects resting in supine position; black and white symbols, data while standing; black symbols, data at different grades of treadmill exercise. Numerals adjacent to the symbols indicate the particular experiment from which data were obtained (Table I).

experiment to experiment in each subject (Figure 3, Table I).

On standing there was an increase in heart rate, little change in systemic blood pressure, and, on eight of the nine occasions, a decrease in cardiac output. The stroke index fell to $30 \mathrm{ml}$ in three subjects (Table II). In R.M. the somewhat higher average value of $38 \mathrm{ml}$ was due to a slight fall to $46 \mathrm{ml}$ on one occasion when the subject was apprehensive; in each of the other two experiments in R.M. the stroke volume fell to $34 \mathrm{ml}$. The average stroke index for all subjects while standing at rest was $32 \mathrm{ml}$. This represents a fall of 41 per cent from the average value of $54 \mathrm{ml}$ in the supine position.

Mild exercise, consisting of alternate contraction and relaxation of the calf muscles, was undertaken by D.W., R.M., and Y.W. The oxygen consumption was increased by less than 50 per cent (average 315 to $415 \mathrm{ml}$ per minute). Cardiac output increased moderately and there was a reduction of 2 to 4 beats per minute in heart rate.
Thus the stroke volume increased almost to the level previously obtained in the supine position (Figure 4). Moderate exercise, achieved by walking uphill at 1.7 to $2.5 \mathrm{mph}$, was associated with a further rise in stroke volume to values similar to those obtained with the subject in the supine position (Tables I and II, Figure 3). Thus, at 1.7 $\mathrm{mph}$ the average stroke index for all subjects was $54 \mathrm{ml}$, and at $2.5 \mathrm{mph}$ it was $56 \mathrm{ml}$, compared with $54 \mathrm{ml}$ at rest in the supine position. Severe exercise, sufficient to increase the cardiac output to between 15 and $25 \mathrm{~L}$ per minute, was accompanied by a further slight though definite rise in stroke volume in the first three subjects (Tables I and II, Figure 3); D.H. did not achieve an output greater than $15 \mathrm{~L}$ per minute, and at this level the stroke volume was slightly less than that when he was at rest in the supine position. The average stroke index at $3.5 \mathrm{mph}$ was $58 \mathrm{ml}$, and at 4.5 $\mathrm{mph}, 59 \mathrm{ml}$.

The first three subjects achieved a cardiac output of $20 \mathrm{~L}$ per minute or more on at least one 
TABLE II

Stroke index and heart rate at rest and during upright exercise*

\begin{tabular}{|c|c|c|c|c|c|c|c|c|c|}
\hline \multirow[b]{3}{*}{ Subj. } & \multirow[b]{3}{*}{ BSA } & \multirow[b]{3}{*}{ Supine } & \multirow[b]{3}{*}{ Standing } & \multicolumn{4}{|c|}{ Stroke index $(\mathrm{ml})$} & \multirow{2}{*}{\multicolumn{2}{|c|}{$\begin{array}{c}\text { Per cent of change at } \\
4.5 \mathrm{mph} \text { above that } \\
\text { at rest }\end{array}$}} \\
\hline & & & & \multicolumn{4}{|c|}{ Walking speed (mph) } & & \\
\hline & & & & 1.7 & 2.5 & 3.5 & 4.5 & Supine & Standing \\
\hline & $m^{2}$ & & & & & & & & \\
\hline $\begin{array}{l}\text { D.W. } \\
\text { R.M. } \\
\text { Y.W. } \\
\text { D.H. }\end{array}$ & $\begin{array}{l}1.91 \\
2.10 \\
1.85 \\
1.73\end{array}$ & $\begin{array}{l}55 \\
54 \\
51 \\
56\end{array}$ & $\begin{array}{l}30 \\
38 \\
30 \\
30\end{array}$ & $\begin{array}{l}59 \\
54 \\
50 \\
53\end{array}$ & $\begin{array}{l}64 \\
52 \\
52 \\
55\end{array}$ & $\begin{array}{l}62 \\
56 \\
62 \\
53\end{array}$ & $\begin{array}{l}60 \\
61 \\
63 \\
51\end{array}$ & $\begin{array}{r}+9 \\
+13 \\
+23 \\
-9\end{array}$ & $\begin{array}{r}+100 \\
+61 \\
+110 \\
+70\end{array}$ \\
\hline \multicolumn{10}{|c|}{ Heart rate (beats per minute) } \\
\hline $\begin{array}{l}\text { D.W. } \\
\text { R.M. } \\
\text { Y.W. } \\
\text { D.H. }\end{array}$ & $\begin{array}{l}1.91 \\
2.10 \\
1.85 \\
1.73\end{array}$ & $\begin{array}{l}68 \\
62 \\
66 \\
65\end{array}$ & $\begin{array}{l}87 \\
81 \\
91 \\
89\end{array}$ & $\begin{array}{r}125 \\
119 \\
120 \\
96\end{array}$ & $\begin{array}{l}141 \\
164 \\
132 \\
126\end{array}$ & $\begin{array}{l}165 \\
171 \\
165 \\
166\end{array}$ & $\begin{array}{l}174 \\
180 \\
174 \\
168\end{array}$ & $\begin{array}{r}+156 \\
+190 \\
+164 \\
+158\end{array}$ & $\begin{array}{r}+100 \\
+122 \\
+91 \\
+77\end{array}$ \\
\hline
\end{tabular}
D.H.

* Table shows average values for all experiments in each of three subjects, and values for the single experiment in

occasion, and heart rates of 174 to 183 beats per minute. The oxygen consumption increased in D.W. to 2,380, in R.M. to 2,820, and in Y.W. to $2,150 \mathrm{ml}$ per minute, in comparison with their respective values of 280,300 , and 280 at rest in the supine position; these increases are 8.5, 9.4, and 7.7 times the values prior to the increase (Figure $5)$. The levels of exercise were approaching the maximum which the subjects could maintain for the necessary 3 minutes. The fourth subject (D.H.) achieved a maximal output of $15.3 \mathrm{~L}$ per minute, a heart rate of 168 beats per minute and an oxygen consumption of $2,030 \mathrm{ml}$ per minute, an increase of 8.0 times the resting value.

Arteriovenous difference in oxygen content was calculated from the oxygen consumption and cardiac output (Figure 6). At rest in the supine position the values were 3.9 to $4.3 \mathrm{ml}$ per $100 \mathrm{ml}$ of blood. With moderate exercise there was an increase to 10 to $12 \mathrm{ml}$ per $100 \mathrm{ml}$. Little further change occurred in the arteriovenous oxygen difference even with the severest exercise undertaken.

Data from the four subjects who performed leg

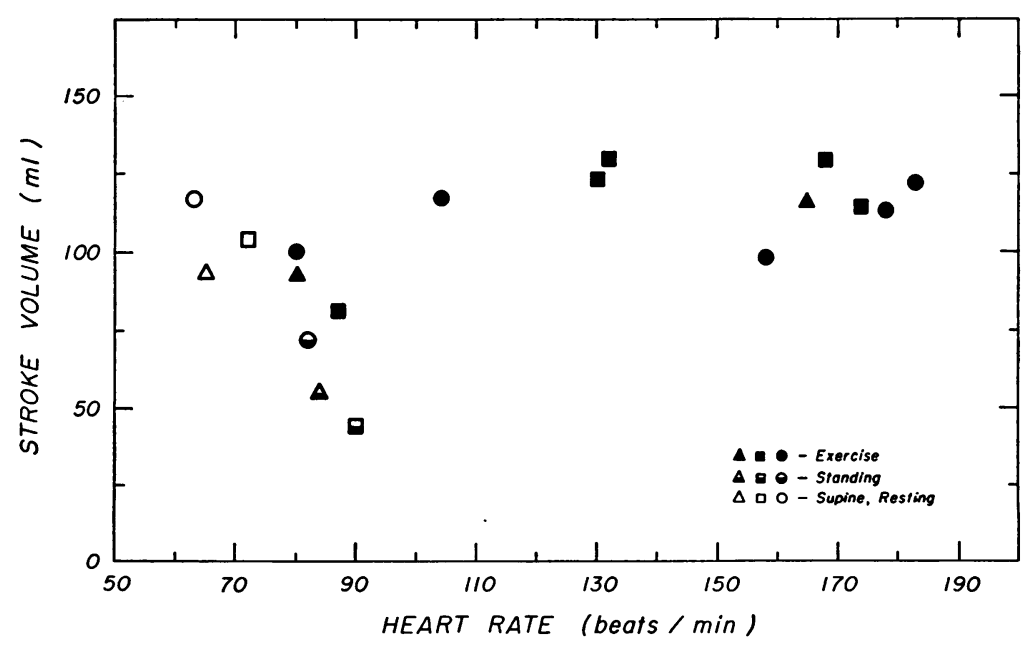

Fig. 4. RELATIONSHiP BETWEen heART RATE AND STROKE VOLUME IN ONE EXPERIMENT FROM EACH OF THREE SUBJECTS. Symbols used are the same as in Figure 3. Note the tachycardia and fall in stroke volume with the subject standing, and the slight bradycardia and marked rise in stroke volume on performing light exercise in the upright position. 


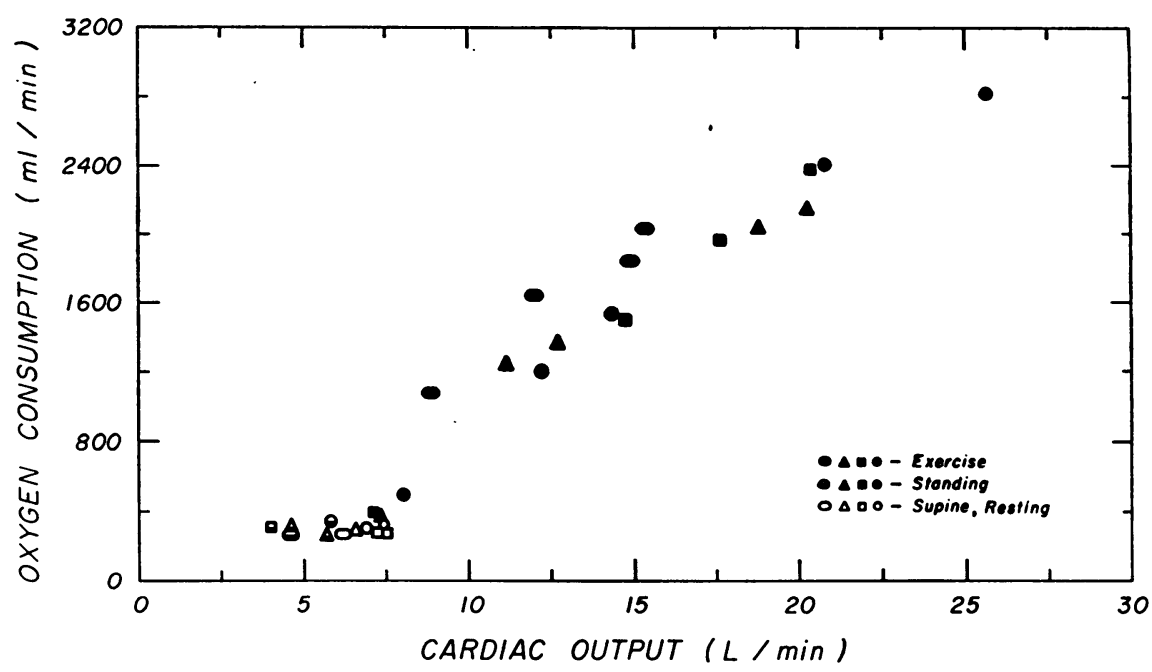

Fig. 5. RELATION BETWEen CARDiaC OUTPUT AND OXYGEN CONSUMPTION AT REST IN THE SUPINE AND THE STANding positions and during exercise. Symbols used are the same as those in Figure 3.

exercise on a cycle ergometer while supine are presented in Table III. The exercise was arbitrarily graded as mild, moderate or severe. There was a definite, though slight, increase in stroke volume during exercise; with the severest exercise the stroke volume was 10 to 20 per cent greater than that while at rest. In Figure 7 the data obtained for Y.W. are compared with those on the other occasions when he exercised in the upright position.
The effects of severe exercise maintained for 10 -minute periods are shown in Figure 8 . In R.M. the pulse rate increased from 80 to 165 beats per minute within 2 minutes and was steady for the remainder of the exercise; the blood pressure increased from $132 / 75$ to $200 / 70 \mathrm{~mm}$ of mercury and also remained fairly steady for the next 8 minutes. Values obtained for cardiac output were about $20 \mathrm{~L}$ per minute at 2 and $3.5 \mathrm{~min}$ utes, $17 \mathrm{~L}$ per minute at the sixth minute and 19

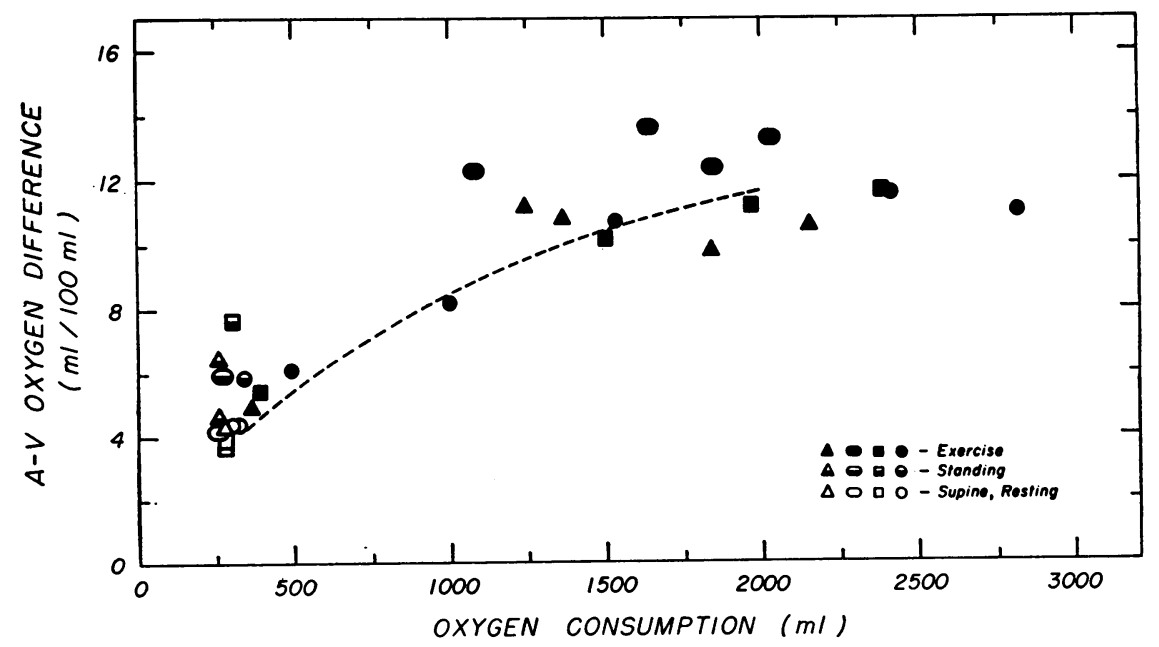

Fig. 6. RELATIONSHiP BETWEEN OXYGEN CONSUMPTION AND ARTERIOVENOUS DifFERENCE IN OXYGEN CONTENT (ONE EXPERIMENT FROM EACH SUBJECT). The lowest values shown were obtained with subject at rest in the supine position. The interrupted line shows the regression line obtained by Donald and associates (6) plotted for the hypothetical man with a body surface area of $1.73 \mathrm{~m}^{2}$. 
TABLE III

Changes in cardiac output, heart rate and stroke volume during exercise while supine

\begin{tabular}{|c|c|c|c|c|c|}
\hline Subj. & Condition & $\begin{array}{l}\text { Cardiac } \\
\text { output }\end{array}$ & $\underset{\text { rate }}{\text { Heart }}$ & $\begin{array}{c}\text { Stroke } \\
\text { volume }\end{array}$ & $\begin{array}{c}\text { Stroke } \\
\text { index }\end{array}$ \\
\hline J.B. & $\begin{array}{l}\text { Rest } \\
\text { Rest } \\
\text { Moderate exercise } \\
\text { Moderate exercise } \\
\text { Severe exercise }\end{array}$ & $\begin{array}{r}L / \min \\
7.30 \\
6.80 \\
12.20 \\
12.60 \\
15.00\end{array}$ & $\begin{array}{c}\text { beats/min } \\
73 \\
71 \\
117 \\
125 \\
140\end{array}$ & $\begin{array}{c}m l \\
100 \\
96 \\
104 \\
101 \\
107\end{array}$ & $\begin{array}{l}m l \\
51 \\
49 \\
53 \\
52 \\
55\end{array}$ \\
\hline W.M. & $\begin{array}{l}\text { Rest } \\
\text { Rest } \\
\text { Severe exercise } \\
\text { Severe exercise }\end{array}$ & $\begin{array}{r}7.25 \\
7.20 \\
16.50 \\
15.95\end{array}$ & $\begin{array}{r}57 \\
57 \\
115 \\
113\end{array}$ & $\begin{array}{l}127 \\
126 \\
143 \\
141\end{array}$ & $\begin{array}{l}59 \\
59 \\
67 \\
66\end{array}$ \\
\hline H.H. & $\begin{array}{l}\text { Rest } \\
\text { Rest } \\
\text { Moderate exercise } \\
\text { Moderate exercise }\end{array}$ & $\begin{array}{r}8.15 \\
7.85 \\
13.90 \\
12.30\end{array}$ & $\begin{array}{r}93 \\
96 \\
142 \\
132\end{array}$ & $\begin{array}{l}88 \\
82 \\
98 \\
93\end{array}$ & $\begin{array}{l}49 \\
46 \\
54 \\
52\end{array}$ \\
\hline Y.W. & $\begin{array}{l}\text { Rest } \\
\text { Rest } \\
\text { Mild exercise } \\
\text { Mild exercise } \\
\text { Moderate exercise } \\
\text { Severe exercise } \\
\text { Severe exercise }\end{array}$ & $\begin{array}{r}5.35 \\
5.65 \\
8.70 \\
8.75 \\
10.90 \\
13.40 \\
15.10\end{array}$ & $\begin{array}{r}59 \\
61 \\
90 \\
89 \\
100 \\
120 \\
138\end{array}$ & $\begin{array}{r}91 \\
93 \\
97 \\
98 \\
109 \\
112 \\
109\end{array}$ & $\begin{array}{l}49 \\
50 \\
52 \\
53 \\
59 \\
61 \\
59\end{array}$ \\
\hline
\end{tabular}

$\mathrm{L}$ per minute at the tenth minute. In Y.W., the pulse rate increased from 80 to 153 beats per minute at the second minute, but continued to rise slowly throughout the period of exercise, reaching 189 beats per minute at the tenth minute. The systolic blood pressure increased by only $10 \mathrm{~mm}$ of mercury; the diastolic pressure initially fell from 75 to about $60 \mathrm{~mm}$ of mercury and then gradually increased to $70 \mathrm{~mm}$ of mercury at the tenth minute. The cardiac output was $7.2 \mathrm{~L}$ per minute with the subject standing at rest; $19 \mathrm{~L}$ at 3.5 minutes of exercise, $22.5 \mathrm{~L}$ at 6 minutes, and $25 \mathrm{~L}$ at the tenth minute; corresponding values for stroke volume were $93,116,130$, and $133 \mathrm{ml}$.

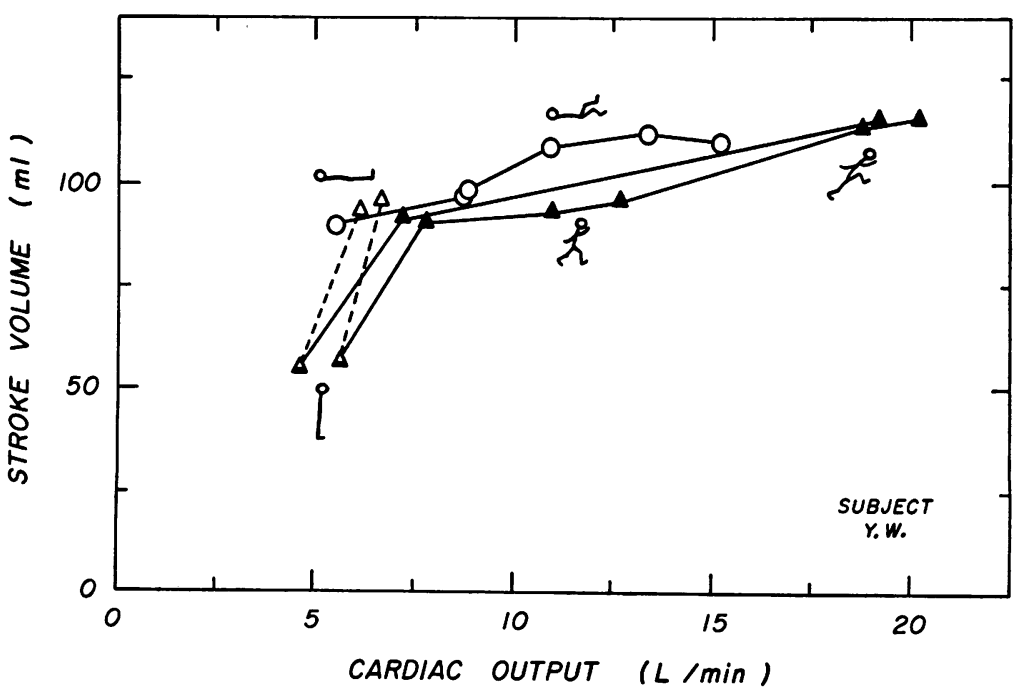

Fig. 7. Changes in Stroke volume in Y.W. DURING Leg exercise while SUPINE (WHITE CIRCLES), COMPARED WITH DATA OBTAINED WITH SUBJECT AT REST AND DURING EXERCISE IN THE UPRIGHT POSITION. Symbols as for Y.W. in Figure 3. 

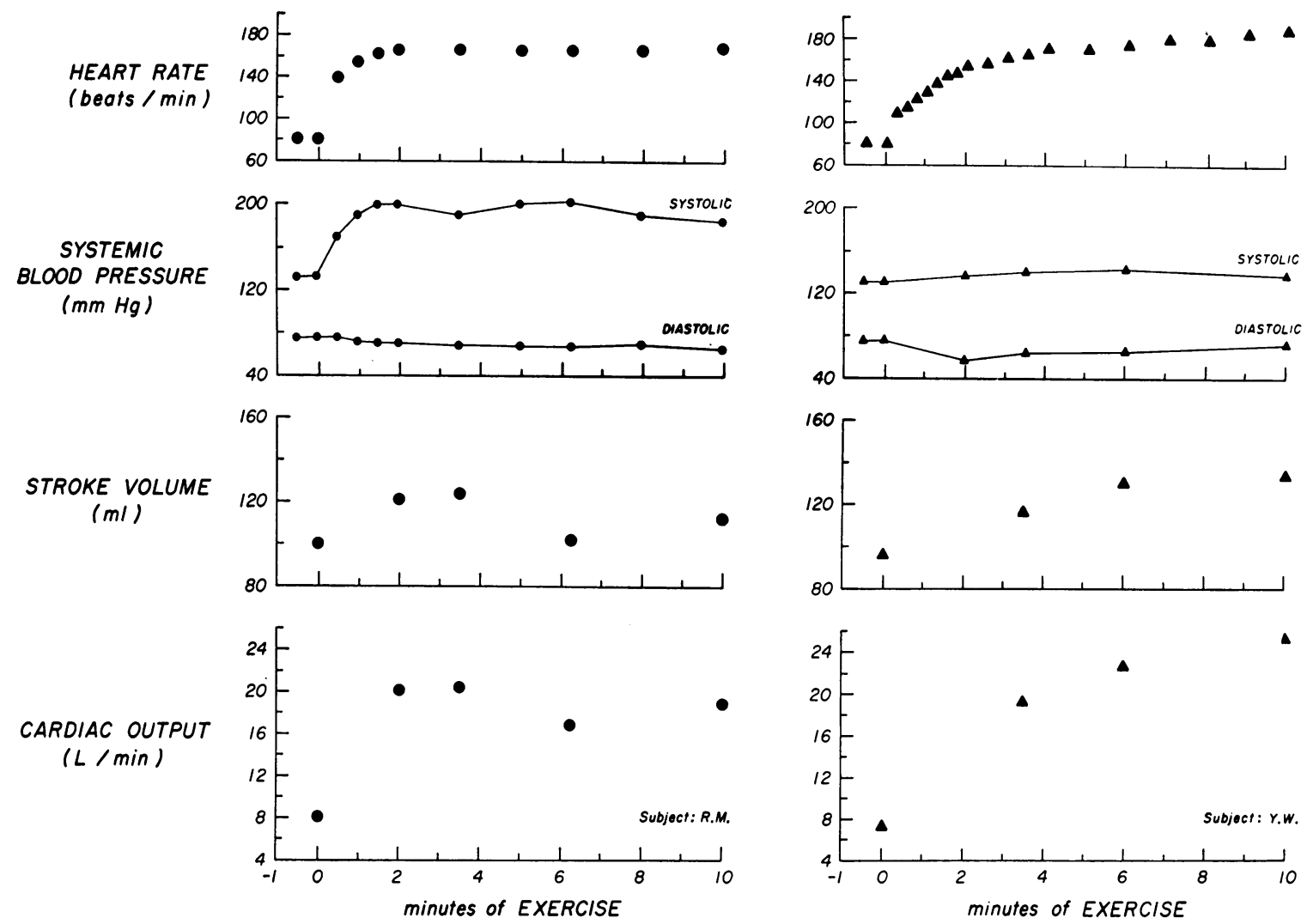

Fig. 8. The effect of continued exercise While upright in R.M. (Left panel) and Y.W. (Right Panel) ON HEART RATE, BLOOD PRESSURE, STROKE VOLUME AND CARDIAC OUTPUT.

\section{DISCUSSION}

Donald, Bishop, Cumming and Wade (6) found that during supine leg exercise the arteriovenous oxygen difference and cardiac output reach a steady state after the first minute. In the present experiments, pulse rate (except in Y.W.) and blood pressure became stable in 1.5 to 2 minutes and cardiac output was therefore determined during the third minute of exercise. However, observations made during prolonged severe upright exercise indicate the difficulty in achieving a steady state under these conditions (Figure 8). Thus, in Y.W. the heart rate and cardiac output continued to rise gradually throughout exercise, while in R.M. the heart rate remained relatively steady. It is difficult for untrained subjects to maintain precisely the same work level during prolonged severe exercise, and a constant treadmill speed is no guarantee that the subject's cardiac output will become steady.

The indicator-dilution technic, when combined with a continuous recording of the changes in dye concentration in arterial blood, is well suited for the determination of cardiac output in man during exercise. It is unnecessary to have a catheter in the pulmonary artery to draw mixed venous blood samples, and a steady state needs to be maintained only during the short time required for inscription of the dilution curve. With higher cardiac outputs, the time required for inscription of the indicator-dilution curve becomes less and with the severest exercise in the present experiments the curve was completed within 20 seconds after the injection of dye.

We believe that, when particular attention is paid to obtaining satisfactory calibration curves for the concentration of dye in blood, and when the dye is injected into the central circulation, the indicator-dilution method accurately measures the cardiac output in resting subjects. However, it is probable that the results are less accurate when cardiac output is greatly increased. Under this 
circumstance, the area subtended by the dilution curve is much less than that during rest, and hence inaccuracies in its measurement are more likely. Further, as a result of the profound alterations in the systemic distribution of blood flow that occur during exercise, clearance of dye from blood at the sampling site between the end of its primary circulation and its first recirculation in some, but not all, subjects is relatively less complete than when they are at rest. Hence, extrapolation of the disappearance slope in an attempt to exclude the measurement of recirculating dye may be subject to more than the usual inaccuracy.

Stroke volume at rest and during exercise in the upright position. The cardiac index in the subjects resting in the supine position averaged $3.5 \mathrm{~L}$. This is similar to values obtained in young adult males of 3.4 (7), 3.3 (8), 3.6 (9), and 3.5 (10) L by the direct Fick method. The stroke index averaged $54 \mathrm{ml}$. When the subject stood, the stroke index fell to an average value of $32 \mathrm{ml}$. Extremely light exercise in the upright position, consisting of contraction and relaxation of the calf muscles but insufficient to increase the oxygen consumption by more than 50 per cent, caused the stroke index to approach the value obtained in the supine position. With exercise resulting in a cardfac index of about 5 to $10 \mathrm{~L}$, the stroke index was similar to that at rest in the supine position, though there were slight variations from one experiment to another. With severe exercise and a cardiac index of up to $12 \mathrm{~L}$, the average value for stroke index for the four subjects was $59 \mathrm{ml}$.

We are aware of only two studies in which cardiac output and heart rates have been measured in subjects at rest, in the standing position and during exercise. Theilen, Gregg and Rotta (11) found an increase in stroke index from $33 \mathrm{ml}$, while the subject stood at rest, to $51 \mathrm{ml}$ during moderate exercise (cardiac index $8 \mathrm{~L}$ ) in seven medical students, at sea level. Mitchell, Sproule and Chapman (12) found an increase in stroke volume from $62 \mathrm{ml}$ while standing to $125 \mathrm{ml}$ during severe exercise when the average cardiac output was $23 \mathrm{~L}$. Our results are similar, the stroke index increasing from 32 to 54 and $56 \mathrm{ml}$ with moderate exercise and to $59 \mathrm{ml}$ with severe exercise. With even the mildest exercise the stroke index increases toward the value obtained while the subject is resting in the supine position, to show only a small further increase above this value even with severe exercise.

Stroke volume during exercise in the supine position. Dexter and co-workers (13) found that light leg exercise while the subject was supine increased the average stroke index from 41 to $51 \mathrm{ml}$ in a group of seven healthy adults. Barratt-Boyes and Wood (10) noted an average increase from 49 to $59 \mathrm{ml}$ with comparable leg exercise in 11 adults. Severe exercise, sufficient to increase the cardiac index to $9 \mathrm{~L}$ or more, was undertaken by four subjects in the study of Donald and associates (6). They noted an average increase in stroke index from $55 \mathrm{ml}$ during rest to $62 \mathrm{ml}$ while exercising. Thus during leg exercise while in the supine position, there is a slight increase in stroke volume. The observation in the present study, that the stroke index increased in four subjects by 10 to 20 per cent during severe exercise, supports this conclusion.

Relation of present findings to those of previous workers. Rushmer (1) has discussed the discrepancies in the findings of earlier workers concerning changes in stroke volume during exercise. In his opinion, "the traditional view that stroke volume and heart rate should increase by relatively similar degrees to achieve greater cardiac output stemmed from indirect measurements involving use of $\mathrm{CO}_{2}$ or foreign gases such as nitrous oxide, acetylene and ethyl iodide. These methods have been largely abandoned in favor of cardiac catheterization and indicator-dilution technics." However, the magnitude of the increase in stroke volume during severe upright exercise depends on the baseline to which it is related (Table II). If this is the value obtained with the subject at rest in the supine position, the increase is slight $(-9$ to +23 per cent) compared with the large increase in heart rate $(+156$ to +190 per cent $)$. If it is the value obtained at rest while standing, the increase is considerable $(+61$ to +110 per cent) and comparable with the increase in heart rate $(+77$ to +122 per cent).

Nevertheless, there is still a conflict between results obtained by the earlicr workers who studied changes in stroke volume in subjects sitting on a bicycle ergometer and exercising. Thus, Douglas and Haldane (14), using the carbon dioxide method, found that the stroke volume was 
the same with the subject supine, sitting on the cycle, or exercising, while Bock and associates (15), also using the carbon dioxide method, found increases of 36 to 110 per cent with exercise in three normal subjects. Henderson, Haggard and Dolley (16), using the ethyl iodide method, found no increase in stroke volume in untrained subjects, but Christensen (17), using the acetylene method, found that it increased from $60 \mathrm{ml}$ during rest to between 100 and $200 \mathrm{ml}$ during exercise. These discrepancies are not necessarily due to inadequacy of technics. The careful study of Asmussen and Nielsen (18), in which stroke volume was measured simultaneously by the indicator-dilution and acetylene methods, with identical results, suggests that the inert gas methods cannot necessarily be regarded as unsuitable for determination of cardiac output. An alternative explanation might be that the posture and degree of relaxation of the subject sitting on the cycle varied. Thus the resting value for stroke volume of $60 \mathrm{ml}$ obtained by Christensen (17) is similar to that of subjects standing in a relaxed manner, while the resting value obtained by Douglas and Haldane (14) was twice as great, suggesting that their subjects may have been sitting in a less relaxed posture.

The present studies suggest that for a given person the stroke volume increases only slightly once exercise has begun, regardless of whether the subject is supine or standing. During rest, however, the value for stroke volume depends on the body position. The results of earlier workers, such as Bock and associates (15), who used the carbon dioxide method and Christensen (17), who used the acetylene method, are consistent with this interpretation.

\section{SUMMARY}

Cardiac output, heart rate, and stroke volume were measured in four healthy, untrained men at rest in the supine position, at rest standing and during exercise in the upright position. The exercise varied in severity from gentle movements of the calf muscles and marking time to walking at $4.5 \mathrm{mph}$ up a treadmill inclined at 12 degrees from the horizontal. This severe exercise was associated with cardiac outputs of 15 to $25 \mathrm{~L}$ per minute and oxygen consumptions of 2.0 to 2.8 $L$ per minute.

The cardiac index of subjects at rest in the supine position averaged $3.5 \mathrm{~L}$, and the stroke index averaged $54 \mathrm{ml}$. When the subject stood, there was a fall in cardiac output and an increase in heart rate. The stroke index averaged $32 \mathrm{ml}$, a fall of 41 per cent. Mild exercise was sufficient to restore the stroke index almost to the value obtained with the subject at rest in the supine position. With moderate exercise in the upright position the stroke index was similar to that obtained when the subject was at rest in the supine position and with the severest exercise it increased to 59 $\mathrm{ml}$.

It is probable that the apparent discrepancies in previous reports were due to variations in the circumstances under which resting values for stroke volume were obtained rather than to inadequate technics for measuring cardiac output. Thus, if the stroke volume obtained during severe exercise in the upright position is compared with that obtained when the subject is at rest in the supine position, the increase is slight $(-9$ to +23 per cent) compared with the increase in heart rate $(+156$ to +190 per cent). If the comparison is made with the value obtained when the subject is standing at rest, the inerease in stroke volume $(+61$ to +110 per cent $)$ is comparable with that in the heart rate $(+77$ to +122 per cent).

\section{ACKNOWLEDGMENT}

We wish to thank Miss Lucille Cronin, Mrs. Jean Frank and Miss Rita Schmelzer for their advice and assistance.

\section{REFERENCES}

1. Rushmer, R. F. Constancy of stroke volume in ventricular responses to exertion. Amer. J. Physiol. 1959, 196, 745 .

2. Rushmer, R. F., and Smith, O. A., Jr. Cardiac control. Physiol. Rev. 1959, 39, 41.

3. Wang, Yang, Shepherd, J. T., and Marshall, R. J. Relative contribution of heart rate and stroke volume to changes in cardiac output in man (abstract). Circulation 1959, 20, 781.

4. Rushmer, R. F. Postural effects on the baselines of ventricular performance. Circulation 1959, 20, 897.

5. Dubois, D., and Dubois, E. F. The measurement of the surface area of man. Arch. intern. Med. 1915, 15,868 . 
6. Donald, K. W., Bishop, J. M., Cumming, G., and Wade, O. L. The effect of exercise on the cardiac output and circulatory dynamics of normal subjects. Clin. Sci. 1955, 14, 37.

7. Cournand, A., Riley, R. L., Bradley, S. E., Breed, E. S., Noble, R. P., Lauson, H. D., Gregersen, M. I., and Richards, D. W. Studies of the circulation in clinical shock. Surgery 1943, 13, 964.

8. Stead, E. A., Jr., Warren, J. V., Merrill, A. J., and Brannon, E. S. The cardiac output in male subjects as measured by the technique of right atrial catheterization. Normal values with observations on the effect of anxiety and tilting. J. clin. Invest. 1945, 24, 326.

9. Ebert, R. V., Borden, C. W., Wells, H. S., and Wilson, R. H. Studies of the pulmonary circulation. I. The circulation time from the pulmonary artery to the femoral artery and the quantity of blood in the lungs in normal individuals. J. clin. Invest. 1949, 28, 1134.

10. Barratt-Boyes, B. G., and Wood, E. H. Hemodynamic response of healthy subjects to exercise in the supine position while breathing oxygen. J. appl. Physiol. 1957, 11, 129.

11. Theilen, E. O., Gregg, D. E., and Rotta, A. Exercise and cardiac work response at high altitude. Circulation 1955, 12, 383.
12. Mitchell, J. H., Sproule, B. J., and Chapman, C. B. The physiological meaning of the maximal oxygen intake test. J. clin. Invest. 1958, 37, 538.

13. Dexter, L., Whittenberger, J. L., Haynes, F. W., Goodale, W. T., Gorlin, R., and Sawyer, C. G. Effect of exercise on circulatory dynamics of normal individuals. J. appl. Physiol. 1951, 3, 439.

14. Douglas, C. G., and Haldane, J. S. The regulation of the general circulation rate in man. J. Physiol. (Lond.) 1922, 56, 69.

15. Bock, A. V., Vancaulaert, C., Dill, D. B., Fölling, A., and Hurxthal, L. M. Studies in muscular activity. III. Dynamical changes occurring in man at work. J. Physiol. (Lond.) 1928, 66, 136.

16. Henderson, Y., Haggard, H. W. and Dolley, F. S. The efficiency of the heart and the significance of rapid and slow pulse rates. Amer. J. Physiol. 1927, 82, 512.

17. Christensen, E. H. Beiträge zur Physiologie schwerer körperlicher Arbeit. V. Mitteilung: Minutenvolumen und Schlagvolumen des Herzens während schwerer körperlicher Arbeit. Arbeitsphysiologie $1931,4,470$.

18. Asmussen, E., and Nielsen, M. The cardiac output in rest and work determined simultaneously by the acetylene and the dye injection methods. Acta physiol. scand. 1953, 27, 217.

\section{ERRATUM}

Shafrir, E., and Steinberg, E. The Essential Role of the Adrenal Cortex in the Response of Plasma Free Fatty Acids, Cholesterol, and Phospholipids to Epinephrine Injection. J. clin. Invest. 1960, 39 (February). The authors report an important error in the Methods section. On p. 310, column 2, line 16, read: "150 $\mathrm{ml}$ acetic anhydride" instead of " $50 \mathrm{ml}$." 